\title{
THE EFFECTS OF ENVIRONMENTAL ENRICHMENT ON BIOCHEMICAL AND METRIC PARAMETERS OF AGED RATS
}

\author{
EFEITOS DO AMBIENTE ENRIQUECIDO EM PARAMETROS BIOQUÍMICOS E \\ MÉTRICOS DE RATOS IDOSOS
}

\author{
Thiago Aparecido VIEIRA ${ }^{1}$; Rodrigo Leal de Paiva CARVALHO²; \\ Sarah Cristina FERREIRA ${ }^{1}$; Ana Paula de OLIVEIRA ${ }^{1}$; Olayr MODESTO JUNIOR ${ }^{3}$; \\ Welton Ferreira de ASSIS ${ }^{4}$; José Alexandre Curiacos de ALMEIDA LEME ${ }^{5}$ \\ 1. Discente do Centro Universitário Católico "Auxilium" Unisalesiano, Lins, SP, Brasil; 2. Docente do Programa de Pós Graduação em \\ Fisioterapia da Universidade Sagrado Coração, Bauru, SP, Brasil; 3. Docente do Centro Universitário Católico "Auxilium" \\ Unisalesiano, Lins, SP, Brasil; 4. Mestrando pelo Programa de Pós Graduação em Ciências da Motricidade, UNESP, Rio Claro, Brasil; \\ 5. Docente do Programa de Pós Graduação em Ciências da Motricidade UNESP-Rio Claro, Unesp-Bauru e Centro Universitário \\ Católico “Auxilium” Unisalesiano, Lins, SP, Brasil;
}

\begin{abstract}
The enriched environment (EE) is a promoter of physical activity, by its characteristics such as ample room for movement and exploration, presence of wheels, tunnels and toys. The maintenance of animals in enriched environment can bring a range of benefits, but the majority of the researches investigate cognitive parameters and changes related to the nervous system. The aim of this study was to examine the effects of the maintenance of aged rats in enriched cages on biochemical and metric parameters. Wistar rats were randomly distributed $(n=6)$ into two groups during 6 weeks: control (C) in a conventional cage and enriched environment (EE). The body mass were recorded weekly and the body length at the end of the study. After euthanasia, blood was collected for analysis of glucose, triglycerides and the brain was collected for analysis of mass. The EE group had higher brain mass and lower gain of body weight compared to control group. The control group animals had normal values of blood glucose and triglyceride levels, and the maintenance in an $\mathrm{EE}$ did not promote changes in these parameters. Therefore, it can be concluded that the EE group increases brain mass and reduces the gain of body weight without changing the blood glucose and triglycerides in aged animals.
\end{abstract}

KEYWORDS: Enriched Environment. Physical Activity, Obesity. Brain Mass.

\section{INTRODUCTION}

The enriched environment (EE) can be defined as "a combination of complex inanimate and social stimulation" which provides the living being that dwelled therein better conditions for its development (ROSENZWEIG, 1978).This concept, applied to animal experimentation, it is basically a way to accommodate the animals in collective cages with large variations of objects that promote cognitive, sensorial, motor and social stimulations. (BLANCO et al., 2012; SZTAINBERG, CHEN, 2010; NITHIANANTHARAJAH, HANNAH, 2006).

Objects that provide the achievement of physical activity in animals confined in the EE, such as wheels are of extreme importance for satisfactory results. The effects EE on the physical aspect, and biochemical analysis of animals confined in this type of housing has been little studied, despite the physical activity be cornerstone between the stimuli provided by EE. (XIE et al., 2013; AUGUSTSSON et al., 2002).

In a relevant study, Kobilo et al. (2011) investigated the effects of physical activity in EE and concluded that this environment can promote some benefits to the organism such as the increase of brain derived neurotrophic factor (BDNF).

In reference to aged animals, physical activity is linked to the non-pharmacological treatment for loss of cognition and also promoting its improvement. The benefits of physical activity can be exemplified as, increase of neurons, improvement of hormonal action, maintenance of healthy weight, and improvement of insulin sensitivity, among others. (HOLLOSZY et al., 2005).

Aging is a natural process that can occur in a healthy way or accompanied by diseases. Even in the case of healthy aging, declines of cognitive functions, sensory, motor and endocrine-metabolic changes may occur (MORA, 2013).

The maintenance of aged animals in enriched environment seems to contribute to better response in cognitive tests and promotion of synaptogenesis, improvement in neurotransmitter systems, dendritic branching, neurogenesis, glycogenesis and neuronal maintenance (MORA, 2013). However, there is a lack of studies involving other aspects of aging. In this way, the present study aimed to investigate the effects of maintenance of 
aged wistar rats in enriched environment based on metric and biochemical parameters.

\section{MATERIAL AND METHODS}

For this study, fourteen Wistar rats (Rattus Norvegicus Albinus Wistar) were kept in conventional cages until completing the age of 17 months maintained under standard conditions of temperature $\left(22-25^{\circ} \mathrm{C}\right)$, relative humidity $(40-60 \%)$ and light/dark cycle with free access to water and food ad libitum. The experiment followed the recommendations of the Brazilian Resolutions on Bioethics in Experiments with Animals (federal law no. 11,794, of October 08, 2008, National Council of Control of Animal Experimentation- CONCEA). When completing seventeen months (senile age), the animals survives during the period (12) were randomly distributed ( $\mathrm{n}=6 \mathrm{rats} / \mathrm{groups}$ ) in Control Group (CG) - conventional cages (40 x $35 \times 17 \mathrm{~cm})$ and Enriched Environment group (EE) - maintained in enriched cage $(1.5 \mathrm{~m} \times 50 \mathrm{~cm} \times 35 \mathrm{~cm})$, during 6 weeks.

\section{Enriched environment}

The EE is a place where objects were displayed to stimulate the animals. In our laboratory, the enriched cage has $1.5 \mathrm{~m} \mathrm{x} 50 \mathrm{~cm}$ x $35 \mathrm{~cm}$ and has inanimate objects such as tunnels, colorful toys and the wheel. This cage was planned and assembled based on the protocols described by Sztainberg and Chen (2010). The animals from EE group were maintained during the entire experimental period in this type of housing. The wheel $(30 \mathrm{~cm}$ in diameter), tunnels and toys were inserted in the environment, with the objective of promoting sensory and cognitive stimuli. These toys were changed weekly in order to keep the intensity of the stimuli. The containers for food and water intake were adapted to allow control inside the cage.

\section{Evaluation after euthanasia}

At the end of the experimental period and after euthanasia, the blood was collected $(1,5 \mathrm{ml})$, and the serum was separated by centrifugation and glucose and triglycerides rates. Glucose level was determined by the glucose-oxidase method utilizing a commercial kit (Laborlab) and triglycerides using lipase process using a commercial kit (Laborlab). The brain was dissected and weighed using analytical scale and the animals had their body length registered using the nose-anal measure.

\section{Statistical analysis}

After the normality test (Shapiro-Wilk's), the results were statistically evaluated using the " $t$ " test, SPSS software ${ }^{\circledR}$. Differences were considered significant with $\mathrm{p}$ values $<0.05$. Results are expressed as Mean \pm Standard Deviation.

\section{RESULTS}

Table 1 presents the data of body mass collected at the end of the experimental period and the weight gain along the experimental period. The body mass shows no difference, but the weight gain was increased in control group compared to environment enriched group.

Table 1. Weight gain (final-initial body weight-g), Body weight, body length $(\mathrm{cm})$ and brain mass $(\mathrm{g})$ of the control or environmental enriched groups at the end of experimental period

\begin{tabular}{ccccc}
\hline Groups & Weight (post) & Weight gain & Length & Brain mass \\
& & & & \\
Control & $476 \pm 51,4$ & $19,2 \pm 3$ & $26,6 \pm 0,8$ & $2,07 \pm 0,04$ \\
EE & $426,8 \pm 41,9$ & $7,2 \pm 4,6^{*}$ & $26,9 \pm 0,9$ & $2,17 \pm 0,08^{*}$
\end{tabular}

Values expressed as media \pm standard deviation.n $=6$. $* \mathrm{C} \neq \mathrm{EE}$ (Student $\mathrm{T}$ test)

In the metric parameters, the body length showed no significant differences at the end of the experimental period, but the EE group had values of brain mass larger than $\mathrm{C}$ (Table 1).

The maintenance in enriched cage not promoted changes in the values of blood triglycerides and glucose in the animals (Figures 1 and 2). 


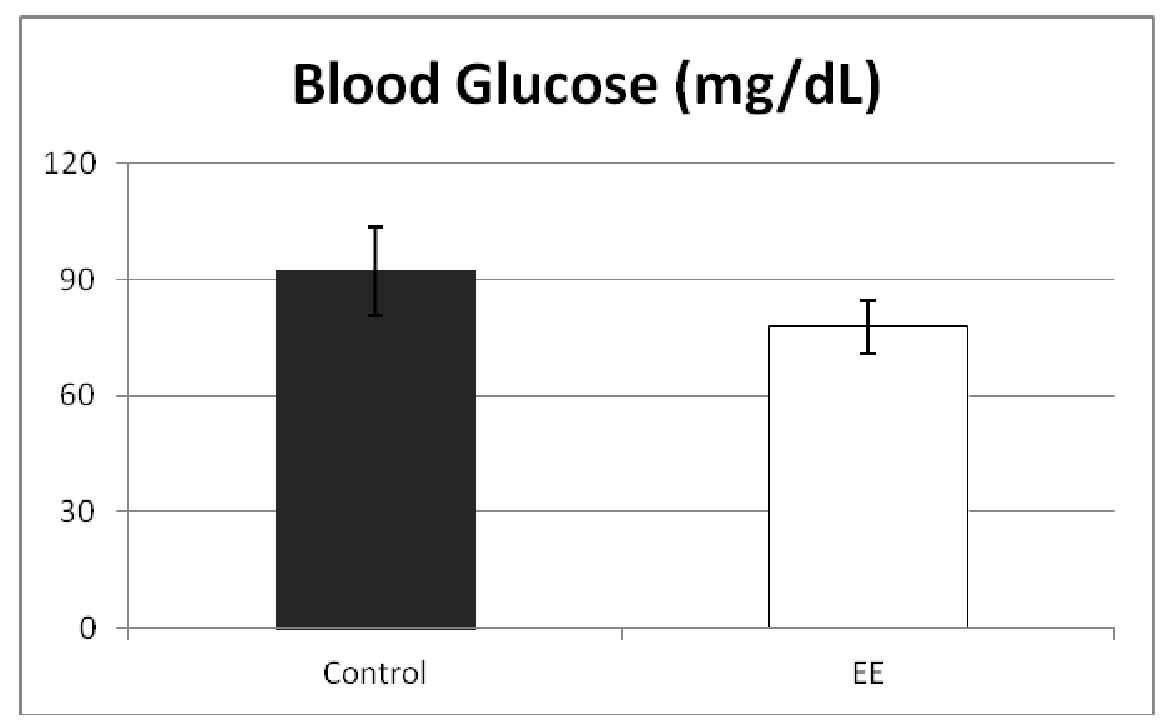

Figure 1. Blood glucose $(\mathrm{mg} / \mathrm{dL})$ levels of the control group and enriched environment (AE) at the end of the experimental period (Values expressed as mean $\pm \mathrm{SD}$; Student's $\mathrm{t}$ test, $\mathrm{n}=6$ rats / group).

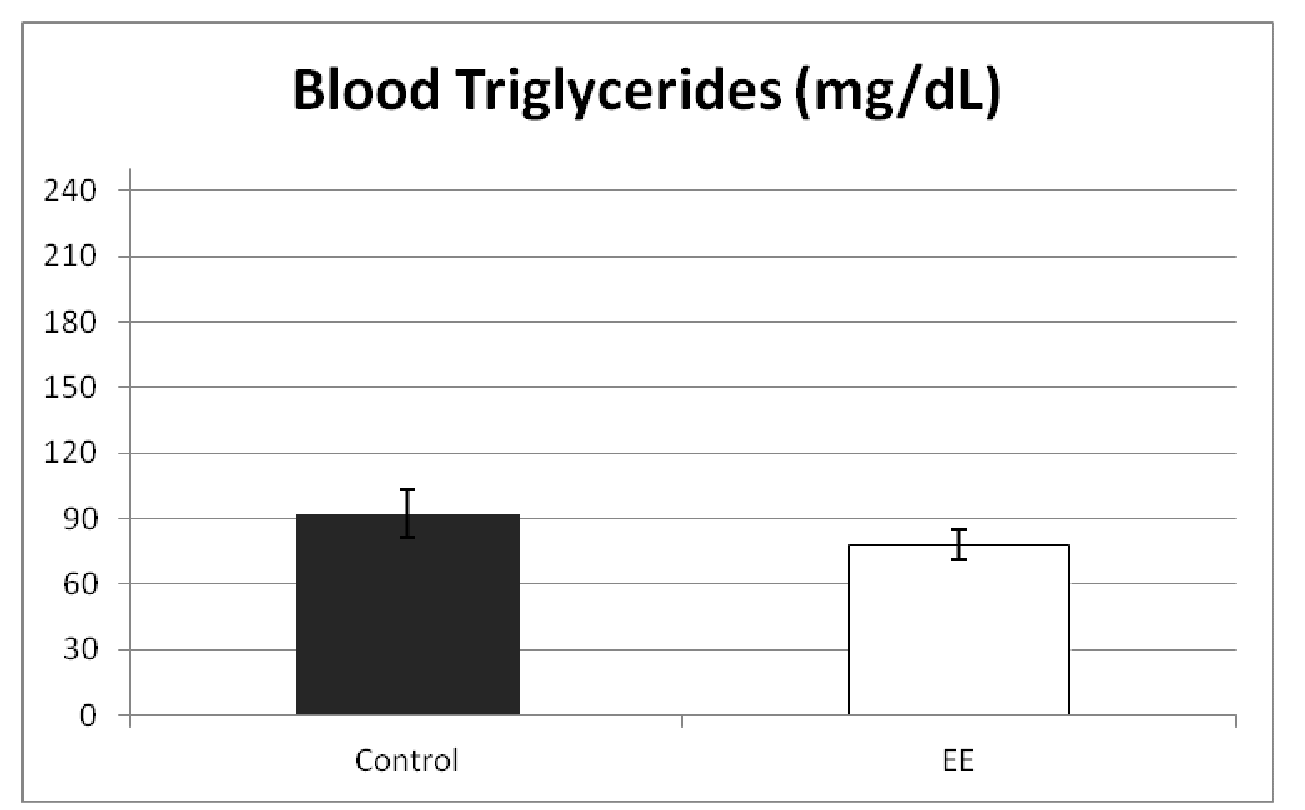

Figure 2. Blood triglycerides ( $\mathrm{mg} / \mathrm{dL}$ ) levels of the control group and enriched environment $(\mathrm{AE})$ at the end of the experimental period (Values expressed as mean \pm SD; Student's t test, $n=6$ rats / group).

\section{DISCUSSION}

The present study investigated the effects of the maintenance of aged rats in the $\mathrm{EE}$ on biochemical and metric parameters. Keeping animals in an EE usually promotes various benefits to the organism. However few studies have investigated biochemical and metric parameters in this environment.

The environmental enrichment promotes a series of sensory, motor, social and behavioral stimuli (SZTAINBERG and CHEN, 2010). Some studies, however, have demonstrated physical activity as a cornerstone for these stimuli. Xie et al. (2013) demonstrated that the keeping animals in EE cause an increase in speed, duration, distance and frequency of movements, proving that the accumulation of physical activity is higher in EE. The physical activity in the EE can promote an increase in energy expenditure. In the present study, at the end of the experimental period the body weight gain of the EE group animals was smaller than the CG group animals. These data corroborate the findings of Harati and his collaborators (2011), but it is important to note that these authors used aged animals (24 weeks) that were kept during 25 weeks on EE, while in this study the animals were kept for only 6 weeks.

Studies involving adult animals showed that the maintenance in enriched cage enables an 
increase in brain mass (HENDERSON, 1970) and promotes an improvement on cognitive function in aged animals (WINOCUR, 1998). In the present study, the Aged EE group animals had brain mass greater than CG animals. In a recent study, Speisman and colleagues (2013) found that the maintenance of aged rats in an enriched cage contributes to improve the cognitive responses in cognitive tests and this occurs as an adaptation to neogenesis promoted by EE (SPEISMAN et al. , 2013).

Another recent study, comparing the effects of EE in adult and aged animals concluded that this type of housing contributes to promoting improvements in cognitive test response, although it promotes brain changes in different regions (MENDES et al., 2013).

Physical activity contributes to the glycemic control, as well as to the reduction of risk factors for the development of diabetes mellitus, in conjunction with diet and drugs. In the literature review, Pauli et al. (2009) stated that the physical training increases glucose uptake by insulin, benefiting the insulin sensitivity thus countering hyperglycemia.

The improvement in insulin sensitivity through the physical activity, is related to the changes in the proteins expression involved in the transport of glucose, such as AMPK and AKT, other factors for the improvement in glycemic profile are explained in the literature, such as a lower concentration of insulin for the transport of glucose, as well as the increase in the translocation of GLUT-4 to the cell surface (HOLLOSZY et al.,
2005). Luciano et al. (2002) showed that the increase in phosphorylation of IRS and increased activity of PI3-kinase induce an improvement on responsiveness to insulin.

Despite the maintenance in enriched environment be a promoter of physical activity, the rats utilized in the present study were not hyperglycemic and, in this way, shows no difference between the groups studied. Takeshita et al. (2012) studied animals kept in conventional cages with wheel for activities and found no reductions in serum glucose and triglyceridemia, despite reduction of hepatic triglyceride.

However, it is important to emphasize that in this study the animals were normoglycemic, as observed in the animals of the control group. This result opens a perspective for future studies using animals hyperglycemic. Similarly there was no significant difference between the groups in triglyceridemia, even being this parameter approximately $30 \%$ lowers in animals kept in EE, in a similar manner to the blood glucose levels.

\section{CONCLUSION}

The aged animals kept in EE showed lower body mass than $\mathrm{CG}$, and an increase in brain mass without changing body length, triglycerides and glucose. Future studies using experimental models that alter glycemic or/and lipidemic homeostasis such as obesity or diabetes can contribute to the clarification of these effects.

\footnotetext{
RESUMO: O ambiente enriquecido (AE) pode ser considerado como promotor de atividade física, pelas suas características como um amplo espaço para deslocamento e exploração, a presença de rodas de atividade, túneis e brinquedos. A manutenção de animais em ambiente enriquecido pode proporcionar uma série de benefícios, mas grande parte dos estudos tem focado a investigação de parâmetros cognitivas e alterações relacionadas ao sistema nervoso. $\mathrm{O}$ objetivo deste estudo foi examinar os efeitos da manutenção de ratos idosos em gaiolas enriquecidas sobre parâmetros bioquímicos e métricas. Ratos Wistar foram distribuídos aleatoriamente $(n=6)$ em dois grupos durante 6 semanas: controle (C) mantido em gaiola convencional e ambiente enriquecido (AE). A massa corporal foi registrada semanalmente e o comprimento corporal ao final do estudo. Após a eutanásia, amostras de sangue foram coletadas para análise de glicose e triglicérides e o encéfalo foi coletado para registro da massa. O grupo AE apresentou maior massa encefálica e menor ganho de peso corporal, em comparação ao grupo controle. Os animais do grupo controle apresentaram valores normais de glicose e triglicerídeos no sangue e a manutenção no AE não promoveu alterações nestes parâmetros. Portanto, pode ser concluído que a manutenção no AE aumenta a massa encefálica e reduz o ganho de peso corporal sem alterar a glicose e triglicerídeos no sangue de animais idosos.
}

PALAVRAS-CHAVE: Ambiente Enriquecido. Atividade Física. Obesidade. Massa Encefálica. 


\section{REFERENCES}

AUGUSTSSON, H.; LINDBERG, L.; HÖGLUND, A. U.; DAHLBORN, K. Human-animal interactions and animal welfare in conventionally and pen-housed rats. Laboratory animals, London, v. 36, n. 3, p. 271-281, 2002.

BLANCO, M.; GON, M.; ESTANISLAU C. Efeitos do Enriquecimento Ambiental na Aprendizagem de Ratos Wistar Jovens e Velhos. Neurobiologia, Recife, v. 75, p. 3-4, 2012.

HARATI, H.; MAJCHRZAK, M.; COSQUER, B.; GALANI, R., KELCHE, C.; CASSEL, J. C.; BARBELIVIEN, A. Attention and memory in aged rats: impact of lifelong environmental enrichment. Neurobiology of aging, New York, v. 32, n. 4, p. 718-736, 2011.

HENDERSON, N. D. Brain weight increases resulting from environmental enrichment: a directional dominance in mice. Science, New York, v. 169, n. 3947, p. 776-778, 1970.

http://dx.doi.org/10.1126/science.169.3947.776

HOLLOSZY, John O. Exercise-induced increase in muscle insulin sensitivity. Journal of Applied Physiology, Washington, v. 99, n. 1, p. 338-343, 2005. http://dx.doi.org/10.1152/japplphysiol.00123.2005

KOBILO, T.; LIU, Q. R.; GANDHI, K.; MUGHAL, M.; SHAHAM, Y.; VAN PRAAG, H. Running is the neurogenic and neurotrophic stimulus in environmental enrichment. Learning \& Memory, Cold Spring Harbor, v. 18, n. 9, p. 605-609, 2011. http://dx.doi.org/10.1101/lm.2283011

LUCIANO, E.; CARNEIRO, E. M.; CARVALHO, C. R.; CARVALHEIRA, J. B.; PERES, S. B.; REIS, M. A.; VELLOSO, L. A. Endurance training improves responsiveness to insulin and modulates insulin signal transduction through the phosphatidylinositol 3-kinase/Akt-1 pathway. European Journal of Endocrinology, Bristol, v. 147, n. 1, p. 149-157, 2002. http://dx.doi.org/10.1530/eje.0.1470149

MENDES, F.; DE ALMEIDA, M. N.; FELÍCIO, A. P.; FADEL, A. C.; DE SILVA, D.; BORRALHO, T. G.; SOSTHENES, M. C. Enriched environment and masticatory activity rehabilitation recover spatial memory decline in aged mice. BMC neuroscience, London, v. 14, n. 1, p. 63, 2013.

MORA, F. Successful brain aging: plasticity, environmental enrichment, and lifestyle. Dialogues in clinical neuroscience, Neuilly-sur-Seine, v. 15, n. 1, p. 45, 2013.

MORA, F.; SEGOVIA, G.; DEL ARCO, A. Aging, plasticity and environmental enrichment: structural changes and neurotransmitter dynamics in several areas of the brain. Brain research reviews, Amsterdam, v. 55, n. 1, p. 78-88, 2007.

NITHIANANTHARAJAH, J.; HANNAN, A. J. Enriched environments, experience-dependent plasticity and disorders of the nervous system. Nature Reviews Neuroscience, London, v. 7, n. 9, p. 697-709, 2006. http://dx.doi.org/10.1038/nrn1970

PAULI, J. R.; CINTRA, D. E.; SOUZA, C. T. D.; ROPELLE, E. R. New mechanisms by which physical exercise improves insulin resistance in the skeletal muscle. Arquivos Brasileiros de Endocrinologia \& Metabologia, Rio e Janeiro, v. 53, n. 4, p. 399-408, 2009.

ROSENZWEIG, M. R.; BENNETT, E. L.; HEBERT, M.; MORIMOTO, H. Social grouping cannot account for cerebral effects of enriched environments. Brain Res. Amsterdam, v. 29, n. 153(3), p. 563-76, 1978.

SPEISMAN, R. B.; KUMAR, A.; RANI, A.; PASTORIZA, J. M.; SEVERANCE, J. E.; FOSTER, T. C.; ORMEROD, B. K. Environmental enrichment restores neurogenesis and rapid acquisition in aged rats. Neurobiology of aging, Fayetteville, v. 34, n. 1, p. 263-274, 2013. 
SZTAINBERG, Y.; CHEN, A. An environmental enrichment model for mice. Nature protocols, London, v. 5, n. 9, p. 1535-1539, 2010.

TAKESHITA, H.; HORIUCHI, M.; IZUMO, K.; KAWAGUCHI, H.; ARIMURA, E.; AOYAMA, K.; TAKEUCHI, T. Long-term voluntary exercise, representing habitual exercise, lowers visceral fat and alters plasma amino acid levels in mice. Environmental health and preventive medicine, Sapporo, v. 17, n. 4, p. 275-284, 2012.

WINOCUR, G. Environmental influences on cognitive decline in aged rats. Neurobiology of aging, Fayetteville, v. 19, n. 6, p. 589-597, 1998.

XIE, H. et al. Enrichment-induced exercise to quantify the effect of different housing conditions: A tool to standardize enriched environment protocols. Behavioural brain research, Amsterdam, v. 249, p. 81-89, 2013. 